\title{
Genetic diversity, chemical composition and oil characteristics of six sesame genotypes
}

\author{
Hamdy A. Zahran ${ }^{1, *}$, Ahmed Abd-Elsaber ${ }^{2}$ and Hesham Z. Tawfeuk ${ }^{3}$ \\ ${ }^{1}$ Fats and Oils Departmctent, Food Industry and Nutrition Research Division, National Research Centre, 12622 Dokki, Cairo, Egypt \\ 2 Oil Crops Research Department, Field Crops Research Institute, Agricultural Research Center, Luxor City, Egypt \\ ${ }^{3}$ Food Sci. \& Tech. Dept., Fac. Agriculture and Natural Resources, Aswan University, Aswan, Egypt
}

Received 25 February 2020 - Accepted 14 July 2020

\begin{abstract}
The nutritional factors and characteristics of sesame (Sesame indicum L.) seeds and extracted oil of six genotypes: G2, G3, G4, G5 and G6 cultivated in Upper Egypt were subjected to comparative evaluation with control (G1), for its genetic diversity, physicochemical properties, fatty acid composition, antioxidant activity and oil oxidative stability (Rancimat test). Estimates of genotypic and phenotypic coefficients of variation revealed high value in seed yield. For heritability estimates, the data showed that four traits out of eight recorded the highest heritability values over of $90 \%$. These traits were oil yield $(99.56 \%)$, seed yield (98.83\%), plant height $(96.33 \%)$ and seed index $(90.03 \%)$. Sesame seeds have a high oil content (39.56 to $54.64 \mathrm{~g} / 100 \mathrm{~g}$ dry weight). The fatty acid profile was varied among the genotypes, in particular oleic acid (37.15 to 46.61\%) and linoleic acid (37.49 to $44.33 \%$ ). Results indicated that G4 has significantly higher in most agricultural traits as well as seed yield, while the G5 was the highest in oil yield and has significantly higher oxidative stability $(26.57 \mathrm{~h})$ among the genotypes.
\end{abstract}

Keywords: genetic diversity / sesame seeds / physicochemical properties / oil yield / fatty acid composition

Résumé - Diversité génétique, composition chimique et caractéristiques des huiles de six génotypes de sésame. Les facteurs nutritionnels et caractéristiques de graines de sésame (Sesame indicum L.) et de l'huile extraite de génotypes (G2, G3, G4, G5 et G6) cultivés en Haute Égypte ont été soumis à une évaluation comparative avec le témoin G1, pour leur diversité génétique, leurs propriétés physicochimiques, leur composition en acides gras, leur activité antioxydante et l'oxydabilité de l'huile (test Rancimat). Les estimations des coefficients de variation génotypiques et phénotypiques ont révélé une valeur élevée du rendement en graines. Concernant les estimations d'héritabilité, les données soulignent que quatre traits sur huit ont montré les valeurs d'héritabilité les plus élevées, supérieures à $90 \%$ : le rendement en huile $(99,56 \%)$, le rendement en graines $(98,83 \%)$, la hauteur de la plante $(96,33 \%)$ et l'indice de graines $(90,03 \%)$. Les graines de sésame affichent une teneur élevée en huile $(39,56$ à $54,64 \mathrm{~g} / 100 \mathrm{~g}$ de poids sec) et leur profil en acides gras varie selon les génotypes, en particulier l'acide oléique (37,15 à 46,61\%) et l'acide linoléique (37,49 à 44,33\%). Les résultats indiquent que G4 a un rendement significativement plus élevé pour la plupart des caractéristiques agricoles ainsi que pour les semences, tandis que G5 possède le rendement en huile le plus élevé et une stabilité à l'oxydation significativement plus élevée $(26,57 \mathrm{~h})$ que les autres génotypes.

Mots clés : diversité génétique / graines de sésame / propriétés physicochimiques / rendement en huile / composition en acides gras

\section{Introduction}

Sesame (Sesame indicum L.) has been considered as "Queen of the oilseeds crops" due to its antioxidants, high oil

\footnotetext{
*Correspondence: hazahran@hotmail.com
}

yield, mildness and pleasant taste of the oil (Bhattachary et al., 2014). It is a member of Pedaliaceae family, the seeds of tropical annual sesamum indicum, originated from dry bush savannah of tropical Africa and then spread to India and China. According to archaeological records, it has been known in India for over 5000 years. This crop is generally cultivated in 
Table 1. The information of studied sesame genotypes in the experiment.

\begin{tabular}{|c|c|c|c|c|c|}
\hline Code & Genotypes & Origin & \multicolumn{3}{|c|}{ Main description } \\
\hline G1 (Control) & Shandaweel 3 & Local genotype & Three & Non branched & White \\
\hline $\mathrm{G} 2$ & Line Zehre 15 Family 2 & Egypt & Three & Branched & White \\
\hline G3 & Line Zehre 11 Family 2 & Egypt & Single & Branched & White \\
\hline G4 & Hybrid 88 Family 2 & Egypt & Single & Branched & Beige \\
\hline
\end{tabular}

${ }^{*}$ Food and Agriculture Organization (FAO).

tropical and temperate regions, the moist soil with minimum irrigation and lack of rainfall results in better yield. The minimum temperature required for sesame germination is between 12 and $14{ }^{\circ} \mathrm{C}$. The normal temperature, which shows the extent with growth blossoms and ripening fruits, is between 25 and $32^{\circ} \mathrm{C}$ (Wei et al., 2017; Aglave, 2018).

Tamina and Dasgupta (2003) and Dossa et al. (2016) noted that the phenotypic coefficient of variation (PCV) was higher than the genotypic coefficient of variation (GCV) for plant height, number of branches/plant, number of capsules/plant, capsules length, seed index (weight of 1000 seeds) and seed yield. Moreover, Ahmed et al. (2013) reported that high estimates of PCV and GCV were exhibited for a number of branches/plant, number of capsules/plant and seed yields/ plant. The high heritability was exhibited for a number of capsules/plant and seed index.

Sesame chemical composition showed that the seed is a principal source of oil (44-58\%), protein (18-25\%), carbohydrate $(13.5 \%)$ and ash (5\%) (Uzun et al., 2002; Were et al., 2006; Elleuch et al., 2007). Environmental conditions and genetic diversity effect on the oil content, as well as fatty acid profile of sesame (Carlsson et al., 2009). Sesame oil contains almost equal levels of oleic (35 to $54 \%$ ) and linoleic (39 to $59 \%$ ), about $10 \%$ of palmitic acid and around $5 \%$ of stearic acid (Wacal et al., 2019). Linolenic acid was found but in very small amount $(0.5 \%)$ (Were et al., 2006). In addition, sesame oil rich in many bioactive compounds, such as tocopherols, phytosterols, and lignans (sesamin, sesamolin, sesamol, pinoresinol and lariciresinol), which play a principal role against oil oxidation and contribute to antioxidative activity (Kanu et al., 2010; Senila et al., 2020).

The oxidative stability of sesame oil is eminent compared to other vegetable oils although it contains nearly $85 \%$ unsaturated fatty acids. This could be due to endogenous antioxidants such as lignans and tocopherols (Abou-Gharbia et al., 2000; Aglave, 2018). Sesame seed oil shows an extraordinary high oxidative stability compared to soybean, corn and most other popular vegetable oils (CarrascoPancorbo et al., 2005; Minioti and Georgiou, 2010).

In Egypt, there is a high shortage in vegetable oils, so that almost $90 \%$ of the consumption needs are currently imported (Zaher et al., 2017). Given that the traditional sesame genotypes were no longer give the desired production, which necessitated a study of the appropriateness of some new genotypes for Egyptian environment, which are characterized by the high yield of oil, as well as study the effect of this on chemical properties of sesame oil. This study was aimed to investigate the genetic diversity effects on physicochemical properties of different genotypes from sesame seeds cultivated in Upper Egypt. As well as, oil characteristics and oxidative stability of extracted sesame oil, as our knowledge the studies on the effect of genetic variation on the oxidative stability of sesame oil is so limited.

\section{Materials and methods}

\subsection{Field trial}

The materials of the present study consisted of six promising genotypes ( 5 new sesame lines and one commercial genotype (Shandaweel-3). The details of tested genotypes are described in Table 1. The lines were evaluated in two successive summer seasons (2017 and 2018), at El-Mtaana Research Station, Agricultural Research Center (ARC), at Luxor Governorate (Coordinates: $25^{\circ} 41^{\prime} \mathrm{N} 32^{\circ} 39^{\prime} \mathrm{E}$ ). Planting date was during April and the harvesting was during August in the two growing season (2017 and 2018). The experiment was laid out using a randomized complete block design (RCBD) with three replications. Each genotype was sown in plots of five rows each of $4-\mathrm{m}$ long, $50-\mathrm{cm}$ width and $20-\mathrm{cm}$ hills within a row. Plants were thinned to one plant per hill. All cultural practices were applied as recommended by Langham (2008) for sesame production at each location.

At harvest, a random sample of 10 plants was taken from each plot in the two growing seasons for the following agronomic characters: (a) Morphological characters: (plant height $(\mathrm{cm})$, length of fruiting zone $(\mathrm{cm})$, number of branches/ plant and number of capsules/plant). (b) Yield parameters: seed yield/plant $(\mathrm{g})$, seed index (weight of 1000 seed) in $\mathrm{g}$, seed yield/hectare (ton) and oil yield/hectare. Three central rows of each plot at each location were taken to determine seed yield in $(\mathrm{kg})$, which was adjusted to calculate yield in ton per hectare.

The mature seeds ( $200 \mathrm{~g}$ ) were milled in a laboratory grinder (Braun $^{\mathrm{TM}}$ GmbH ZK 100, Marktheidenfeld, Germany), after which the ground samples were sieved (sieve mesh No.18) to obtain a powdered processed sample with particle size about $1 \mathrm{~mm}$. Then, ground samples were stored in glass containers at a temperature of $-18^{\circ} \mathrm{C}$ for further analysis.

\subsection{Chemical analysis}

All solvents and chemicals were in analytical grade and purchased from Merck, Darmstadt (Germany). 


\subsubsection{Chemical analysis of sesame seeds}

The samples of sesame genotype and control were analysed for moisture, protein $\left(\% \mathrm{~N}^{*} 6.25\right)$, ash, fat, and fibre according to methods described in AOAC (2000). Total carbohydrates were calculated by difference $[100-$ (protein + fat + ash)] on the dry weight.

\subsubsection{Oil extraction from sesame seeds}

Extraction of the oil was carried out using fully automatically extraction system SOXTHERM ${ }^{\mathrm{TM}}$ (Gerhardt $\mathrm{GmbH} \& \mathrm{Co}$. KG, Germany) with four heating places. The extraction solvent was $n$-hexane.

\subsubsection{Physiochemical properties of sesame oils}

Refractive index (RI) peroxide value (PV), acid value (AV), Iodine value (IV) and unsaponifiable matter for oil samples were determined (in triplicate) according to the official methods AOCS (1997).

\subsubsection{Photometric color index $(\mathrm{PCl})$}

Photometric color index (PCI) is a calculated value that equals the Lovibond $R$-value. The PCI was determined using spectrophotometric method measuring absorbency for four lengths of light waves: 460, 550, 620 and $670 \mathrm{~nm}$. Photometric color index (PCI) was calculated as follows:

$$
\begin{aligned}
P C I & =1.29\left(A_{460}\right)+69.7\left(A_{550}\right)+41.2\left(A_{620}\right) \\
& -56.4\left(A_{670}\right)
\end{aligned}
$$

Where: $A_{460}, A_{550}, A_{620}, A_{670}$ are values of absorbance measured for four wavelengths of light waves: 460, 550, 620 and $670 \mathrm{~nm}$ respectively (AOCS, 1997).

\subsubsection{Fatty acid composition}

Fatty acid composition of the oil was determined according to the modified method of Zahran and Tawfeuk (2019). The fatty acids methyl esters (FAMEs) were analysed by gas chromatography (GC-FID). The FAMEs were separated with an HP 6890 plus gas chromatography (Hewlett Packard, USA), using a capillary column Supelco ${ }^{\mathrm{TM}}$ SP-2380 capillary column $(30 \mathrm{~m} \times 0.25 \mathrm{~mm} \times 0.20 \mu \mathrm{m}) \quad$ (Sigma-Aldrich, USA). The detector (FID) and the injection temperature was $260^{\circ} \mathrm{C}$. The column temperature was $50^{\circ} \mathrm{C}(3 \mathrm{~min})$ to $225^{\circ} \mathrm{C}$ $(17.5 \mathrm{~min})$ at $10^{\circ} \mathrm{C} / \mathrm{min}$. and hold at $225^{\circ} \mathrm{C}(10 \mathrm{~min})$. The carrier gas was helium at a flow rate of $1.2 \mathrm{~mL} \mathrm{~min}^{-1}$. FAMEs were identified by comparing their relative and absolute retention times to those of authentic standards of FAMEs from $\mathrm{C}_{4: 0}$ to $\mathrm{C}_{24: 0}$, (Sigma-Aldrich $\mathrm{GmbH}$, Steinheim, Germany.

\subsubsection{Total phenolic content (TPC)}

Total phenolic content was determined using the FolinCiocalteu method according to the method described by Zahran and Najafi (2019). Sesame oil (2.5 g) was dissolved in $5 \mathrm{~mL}$ organic solvent ( $n$-hexane). Then, TPC extraction was performed using aqueous methanol/water $(80: 20, \mathrm{v} / \mathrm{v})$. The aqueous phase was separate and collected by centrifugation at
$3500 \mathrm{rpm}$ for $5 \mathrm{~min}$. In $5 \mathrm{~mL}$ of aqueous methanol, the dried sample was dissolved and mixed with $2.5 \mathrm{~mL}$ of Folin reagent, then in $50 \mathrm{~mL}$ volumetric flask, $10 \mathrm{~mL}$ of sodium carbonate solution was added and the volume was adjusted by deionized water. The absorbance was measured at $765 \mathrm{~nm}$ after $30 \mathrm{~min}$. The results were expressed as mg gallic acid equivalent (GAE/ $100 \mathrm{~g}$ of oil samples) using gallic acid calibration curve.

\subsubsection{Antioxidant activity by DPPH method}

Antioxidant activities of the extracts, as well as a standard sample of ascorbic acid, were evaluated through using 1,1diphenyl-2-picrylhydrazyl (DPPH) radical assay as reported by Naeem et al. (2019). Two $\mathrm{mL}$ of $0.1 \mathrm{mM} \mathrm{DPPH}$ of the methanolic solution was added into $20,40,60,80$ and $100 \mu \mathrm{g}$ of the extracts and then $1 \mathrm{~mL}$ methanol was added. The mixture was thoroughly mixed and kept in a dark place for $30 \mathrm{~min}$. The control was prepared by mixing $1.5 \mathrm{~mL}$ of DPPH and $1 \mathrm{~mL}$ methanol. Ascorbic acid was considered a standard. The absorbance of the mixture was recorded at $517 \mathrm{~nm}$ using a spectrophotometer (Shimadzu UV-2550; Shimadzu, Kyoto, Japan) and percentage inhibition was calculated from the following equation:

$$
\text { DPPH inhibition }(\%)=\frac{A_{\text {Control }}-A_{\text {Sample }}}{A_{\text {Control }}} \times 100 .
$$

The antioxidant activity of the extracts expressed as $\mathrm{IC}_{50}$ values, which is calculated from the inhibition percent versus concentration plot. The $\mathrm{IC}_{50}$ value indicates concentration (in $\mu \mathrm{g} \mathrm{mL}^{-1}$ ) of the extract, which is required to scavenge $50 \%$ of DPPH free radicals.

\subsubsection{Radical scavenging activity by ABTS method}

The ABTS assay is colorimetric based on the ABTS cation radical formation (Otieno et al., 2016). The radical formation was catalyzed by the reduction of hydrogen peroxide. The ABTS cation radical exhibits a change of color from slightly yellow to an intensely turquoise-colored solution with an absorbance at $734 \mathrm{~nm}$. The radical cation $\mathrm{ABTS}^{+}$is generated by persulfate oxidation of ABTS. A mixture $(1: 1, \mathrm{v} / \mathrm{v})$ of ABTS $(7.0 \mathrm{mM})$ and potassium persulfate $(2.45 \mathrm{mM})$ was mixed and allowed to stand $16 \mathrm{~h}$ at room temperature in a dark place to form radical cation $\mathrm{ABTS}^{+}$(Blue-green color). A working solution was diluted with ethanol to the absorbance value of 0.7 at $734 \mathrm{~nm}$. An aliquot of $100 \mu \mathrm{L}$ of each sample was mixed with the working solution $(2.9 \mathrm{~mL})$ and the decrease of absorbance was measured at $734 \mathrm{~nm}$ after standing $6 \mathrm{~min}$ at room temperature in the dark. Ethanol $(3 \mathrm{~mL}$, without $\mathrm{ABTS}^{+}$solution) was used as the control. Percentage ABTS inhibition was calculated using the formula:

$$
\text { ABTS inhibition }(\%)=\frac{A_{\text {Control }}-A_{\text {Sample }}}{A_{\text {Control }}} \times 100 \text {. }
$$

\subsubsection{Oxidative stability of sesame oil samples (Rancimat test)}

For determination of oxidative stability of oils, AOCS Official Method Cd 12b-92 (AOCS, 1997) was used. The test 
H.A. Zahran et al:: OCL 2020, 27, 39

Table 2. Combined analysis of variance and covariance of a randomized complete block design for 2017 and 2018 seasons.

\begin{tabular}{|c|c|c|c|c|c|}
\hline Source of variation & D.F & \multicolumn{2}{|r|}{ ANOVA } & \multicolumn{2}{|c|}{ ANOCOVA } \\
\hline $\begin{array}{l}\text { Environments (years) } \\
\text { Reps/years } \\
\text { Genotypes } \\
\text { Environ. } \times \text { genotypes } \\
\text { Error }\end{array}$ & $\begin{array}{l}n-1 \\
n(r-1) \\
a-1 \\
(n-1)(a-1) \\
n(r-1)(a-1)\end{array}$ & $\begin{array}{l}\mathrm{Ma} \\
\mathrm{Mas} \\
\mathrm{Me}\end{array}$ & $\begin{array}{l}\sigma^{2} \mathrm{e}+r \sigma^{2} \mathrm{gs}+\mathrm{rn} \sigma^{2} \mathrm{~g} \\
\sigma^{2} \mathrm{e}+r \sigma^{2} \mathrm{gs} \\
\sigma^{2} \mathrm{e}\end{array}$ & $\begin{array}{l}\text { Mp a } \\
\text { Mp as } \\
\text { Mp }\end{array}$ & $\begin{array}{l}\text { Cov } \mathrm{e}+\mathrm{r} \\
\text { Covgs }+\mathrm{rnCov} \mathrm{g} \\
\text { Cov } \mathrm{e}+r \\
\text { Covgs } \\
\text { Cov e }\end{array}$ \\
\hline
\end{tabular}

Table 3. Individual and combined analysis of variance in the three years for six sesame genotypes.

\begin{tabular}{|c|c|c|c|c|c|c|c|c|c|}
\hline S.O.V & df & Plant height & Fruiting zone & No. branches & No. capsules & Seed yield/plant & $\begin{array}{l}\text { Seed yield } \\
\text { (ton/ha) }\end{array}$ & Seed index & $\begin{array}{l}\text { Oil yield } \\
\text { (ton/ha) }\end{array}$ \\
\hline \multicolumn{10}{|l|}{2017} \\
\hline Gen. & 5 & $525.07^{* *}$ & $163.82^{*}$ & $4.09^{* *}$ & $3426.86^{* *}$ & $11.32^{* *}$ & $0.090^{* *}$ & $0.53^{* *}$ & $0.23^{* *}$ \\
\hline Error & 10 & 5.17 & 21.66 & 0.26 & 26.66 & 0.16 & 0.002 & 0.00 & 0.002 \\
\hline \multicolumn{10}{|l|}{2018} \\
\hline Gen. & 5 & $867.92^{* *}$ & $399.97^{*}$ & $3.87^{* *}$ & $1619.16^{* *}$ & 8.95 & 0.05 & $0.52^{* *}$ & $0.32^{* *}$ \\
\hline Error & 10 & 74.52 & 84.63 & 0.43 & 9.59 & 2.33 & 0.01 & 0.00 & 0.02 \\
\hline \multicolumn{10}{|l|}{ Combined } \\
\hline Years & 1 & $4.69^{* *}$ & $7950.69^{* *}$ & 0.44 & $90.25^{* *}$ & $75.40^{* *}$ & $1.92^{* *}$ & 0.00 & $2.48^{* *}$ \\
\hline $\operatorname{Rep} / Y$ & 4 & 12.28 & 13.78 & 0.61 & 34.22 & 0.99 & 0.01 & 0.01 & 0.01 \\
\hline
\end{tabular}

was performed on an automated Metrohm ${ }^{\mathrm{TM}}$ Rancimat model 743 (Herisau, Switzerland) at $110 \pm 0.1^{\circ} \mathrm{C}$ and an airflow of $20 \mathrm{~L} \mathrm{~h}^{-1}$, to determine the induction period (IP) of the oil samples.

\subsection{Statistical analysis}

The values of the means were statistically analysed using SPSS computer software (version 17.0, 2009). The calculation comprised by analysis of variance one-way ANOVA and followed by TUKEY honesty test according to Steel et al. (1997). According to the homogeneity test, the results of 2017 and 2018 did not differ significantly. The data of the two seasons were combined and analysed as such. The individual and combined analyses of variance over two years were performed for studied traits. The analyses were used to estimate the phenotypic, genotypic, environmental variances, heritability, genotypic (GCV) and (PCV) coefficients of variability. Coefficients of phenotypic correlations between each pair of studied traits were also estimated in Table 2 .

Where: $n, r$ and $a$ number of environments, replications and genotypes, respectively. Phenotypic variance $\sigma^{2}$ ph was computed according to the following formula:

$$
\sigma^{2} \mathrm{ph}=\sigma^{2} \mathrm{~g}+\left(\sigma^{2} \mathrm{gs} / \mathrm{n}\right)+\left(\sigma^{2} \mathrm{e} / \mathrm{rn}\right)
$$

Where, $r=$ number of replicates; $n=$ number of environment (years), $\quad \sigma^{2} \mathrm{gs}=(\mathrm{Mas}-\mathrm{Me}) / r, \quad$ and $\sigma^{2} \mathrm{e}=\mathrm{Me}$ (error mean square).

Genotypic and Phenotypic covariance were calculated in the same way. Genotypic and phenotypic coefficients of variance were calculated according to Burton (1951) as follows:

$$
\begin{aligned}
\text { G.C.V. } & =(\sigma \mathrm{p} / \mathrm{X}) \times 100, \text { and P.C.V. } \\
& =(\sigma \mathrm{g} / \mathrm{X}) \times 100 .
\end{aligned}
$$

Broad sense heritability $(\mathrm{H})$ was calculated as described by Hanson (1963) using the following formula:

$$
\mathrm{H}=\left(\sigma^{2} \mathrm{~g} / \sigma^{2} \mathrm{ph}\right) \times 100 .
$$

\section{Results and discussion}

\subsection{Agronomic characteristics}

\subsubsection{Variance and means}

The individual and combined analysis of variances (Tab. 3) showed that the genotype variance was significant for all the studied traits except seed yield/plant in season 2018. 
H.A. Zahran et al:: OCL 2020, 27, 39

Table 4. Mean values of yield and related characters as affected by sesame genotypes (combined analysis over 2017 and 2018 seasons.

\begin{tabular}{|c|c|c|c|c|c|c|c|c|c|}
\hline Parameters & \multicolumn{6}{|c|}{ Sesame genotypes } & Mean & \multicolumn{2}{|c|}{ Range } \\
\hline Plant height $(\mathrm{cm})$ & $170.33^{\mathrm{d}}$ & $208.50^{\mathrm{a}}$ & $199.17^{\mathrm{ab}}$ & $186.33^{\mathrm{c}}$ & $208.83^{\mathrm{a}}$ & $189.00^{\mathrm{bc}}$ & 193.69 & 170.33 & 208.83 \\
\hline Length of the fruiting zone $(\mathrm{cm})$ & $123.50^{\mathrm{a}}$ & $121.67^{\mathrm{a}}$ & $115.83^{\mathrm{ab}}$ & $105.50^{\mathrm{b}}$ & $105.67^{\mathrm{b}}$ & $104.00^{\mathrm{b}}$ & 112.69 & 104.00 & 123.50 \\
\hline Number of branches/plant & $1.00^{\mathrm{c}}$ & $3.83^{\mathrm{a}}$ & $3.00^{\mathrm{ab}}$ & $2.67^{\mathrm{b}}$ & $3.50^{\mathrm{ab}}$ & $3.33^{\mathrm{ab}}$ & 2.89 & 1.00 & 3.83 \\
\hline Number of capsules/plant & $144.50^{\mathrm{b}}$ & $153.33^{\mathrm{a}}$ & $127.50^{\mathrm{c}}$ & $97.67^{\mathrm{e}}$ & $106.83^{\mathrm{d}}$ & $83.00^{\mathrm{f}}$ & 118.81 & 83.00 & 153.33 \\
\hline Seed index (1000 seed weight in $\mathrm{g})$ & $3.75^{\mathrm{c}}$ & $4.24^{\mathrm{a}}$ & $3.59^{\mathrm{d}}$ & $4.24^{\mathrm{a}}$ & $3.99^{\mathrm{b}}$ & $3.19^{\mathrm{e}}$ & 3.84 & 3.19 & 4.24 \\
\hline Oil yield (ton/ha) & $0.814^{\mathrm{b}}$ & $0.858^{\mathrm{ab}}$ & $0.610^{\mathrm{c}}$ & $0.964^{\mathrm{a}}$ & $0.966^{\mathrm{a}}$ & $0.945^{\mathrm{a}}$ & 0.859 & 0.610 & 0.966 \\
\hline
\end{tabular}

Values in the same row followed by different letters are statistically different at the $95 \%$ confidence level.

Moreover, the difference between years was significant for all the studied traits except seed index. The genotypes/year interaction was highly significant for all studied traits except length of fruiting zone, seed index, seed yield/ha and oil yield/ ha which was not significant. These results reflect the importance of genotypes as a source of variance. Many researchers observed high variance for yield component traits among sesame genotypes, in addition they found an important role of sesame genotypes as a main source of variance (Sankar and Kumar, 2003; Gnanasekaran et al., 2008). In addition, the genotype and climate changes (rainfall and temperature) could have played an effect, for example, unusually high temperatures through short intervals of time could significantly negatively affect crop growth and yield (Wheeler et al., 2000).

\subsubsection{Morphological characteristics}

Wide range of variability was recorded for some morphological characters in Table 3. The differences among genotypes were significant for plant height; length of fruiting zone; the number of branches/plant, and number of capsules/ plant. The overall averages of plant height, Length of the fruiting zone number of branches/plant and the number of capsules/plant were 193.69, 112.69, 2.89 and 118.81 respectively. The range of plant height was from 170.33 for G1 to 208.83 for G5. All genotypes were taller than that of G1. Results showed that G1 and G2 had significantly higher length of fruiting zones compared with G4, G5 and G6 whereas there were no statistical differences between $\mathrm{G} 3$ and the rest of the genotypes (Tab. 4). With respect to a number of branches/plant ranged from 1.00 for $\mathrm{G} 1$ to 3.83 for $\mathrm{G} 2$. The results revealed that there was a wide range in a number of capsules/plant varied from 83.00 to 153.33 with an average of 118.81 . The G2 produced the highest number of capsules/plant (153.33) followed by G1 (144.50) whereas G6 gave the lowest number of capsules/plant being 83.00.

Similar results have been reported by Hassan and Sedeck (2015); Abd El-Rhman and Shafi (2016) for seed yield/plant, oil yield/plant, number of capsules/plant and number of branches/plant, Hika et al. (2015) for biological yield per plant.

\subsubsection{Yield contributing characteristics}

Mean performances and range for seed yield/ha, seed yield/ plant, the seed index and oil yield/ha of six sesame genotypes over the two seasons are presented in Table 4. Results in Table 4 revealed that all genotypes had significantly seed yield/ plant whereas no statistical differences were found between G1, G3 and G5. The data presented in Table 4 showed that seed yield was high in G2, G3 and G5, could it be explained by the high plant height, number of branches/plant and numbers of capsules/plant (Abd-Elsaber and Teileb, 2019).

Significant difference in oil yield/ha was detected among sesame entries over two seasons. Seed yield/ha ranged from 1.56 ton for G3 to 1.95 ton for G4. The G4 significantly exceeded the yield of G1 by about $1.7 \%$; it ranked the first in seed yield/ plant, number of branches/plant, number of capsules/plant and seed index, and the second-highest genotype in the length of the fruiting zone and oil yield/ha. Results showed that G5, G4 and G6 had significantly higher oil yield compared with G2 and G6, whereas while G3 recorded the lowest oil yield by 0.61 ton/ha (Tab. 4). The obtained results by Hassan and Sedeck (2015), Abd El-Rhman and Shafi (2016), Abd-Elsaber et al. (2018) were in same manner of most studied traits.

\subsubsection{Genetic effect}

The estimates of genetic variance $\left(\sigma^{2} \mathrm{~g}\right)$, phenotypic $\left(\sigma^{2} \mathrm{ph}\right)$ and environment $\left(\sigma^{2} \mathrm{e}\right)$ variance, genotypic $(\mathrm{GCV})$ and phenotypic (PCV) coefficient of variability broad-sense heritability and expected genetic advance (GS) under 5\% selection on the intensity and as a percentage of the general mean (GS\%) are presented in Table 4. The highest values of phenotypic, genotypic and environment variances ware 834.96, 679.07 and 155.89 for the number of capsules/plant and 215.88, 207.96 and 7.93 for plant height. On the other hand, seed yield/ha had the lowest value of phenotypic, genotypic and environment variances were $0.021,0.021$ and 0.0 , respectively. These results are in confirmatory with these of Kumar and Sasivannan (2006), El-Shakhess et al. (2008), Abd-Elsaber and Teileb (2019).

The extent of the coefficient of variation indicated that high estimates of (PCV) and (GCV) were exhibited for the number of branches/plant and number of capsules/plant. The GCV for the number of branches/plant and number of capsules/plant were 29.19 and 21.93 respectively, suggesting a wide spectrum of genotypic variation for these traits. Low magnitude GCV and PCV were observed for seed yield/plant, plant height and length of the fruiting zone. 
H.A. Zahran et al:: OCL 2020, 27, 39

Table 5. The genetic effects on yields and some agronomic characters of six sesame genotypes over 2017 and 2018 seasons.

\begin{tabular}{|c|c|c|c|c|c|c|c|c|}
\hline Characters & \multicolumn{3}{|c|}{ Component of variance } & \multicolumn{2}{|c|}{ Genetic variability } & $h^{2} b \%$ & \multicolumn{2}{|c|}{ Genetic advance } \\
\hline Plant height & 207.96 & 215.88 & 7.93 & 7.59 & 7.45 & 96.33 & 29.20 & 15.07 \\
\hline Length of fruiting zone & 59.58 & 76.25 & 16.67 & 7.75 & 6.85 & 78.13 & 14.08 & 12.49 \\
\hline Number of branches/plant & 0.71 & 1.21 & 0.50 & 38.09 & 29.19 & 58.72 & 1.33 & 46.14 \\
\hline Number of capsules/plant & 679.07 & 834.96 & 155.89 & 24.32 & 21.93 & 81.33 & 48.48 & 40.81 \\
\hline Seed index (1000 seed weight) & 0.16 & 0.17 & 0.02 & 10.90 & 10.34 & 90.03 & 0.78 & 20.25 \\
\hline Oil yield/ha & 0.016 & 0.016 & 0.000 & 14.91 & 14.88 & 99.56 & 0.26 & 30.63 \\
\hline
\end{tabular}

$\sigma^{2} \mathrm{~g}=$ genetic variance; $\sigma^{2} \mathrm{ph}=$ phenotypic variance; $\sigma^{2} \mathrm{e}=$ environmental variance.

Table 6. Gross chemical composition of sesame genotypes.

\begin{tabular}{|c|c|c|c|c|c|c|}
\hline Parameters & \multicolumn{6}{|c|}{ Sesame genotypes } \\
\hline Moisture content $(\%)$ & $5.83^{\mathrm{a}} \pm 0.11$ & $4.51^{\mathrm{d}} \pm 0.12$ & $5.27^{\mathrm{c}} \pm 0.15$ & $5.66^{\mathrm{b}} \pm 0.34$ & $5.82^{\mathrm{a}} \pm 0.31$ & $5.15^{\mathrm{d}} \pm 0.17$ \\
\hline Oil content $(\%)$ & $41.12^{\mathrm{d}} \pm 2.20$ & $45.65^{\mathrm{c}} \pm 1.94$ & $39.56^{\mathrm{de}} \pm 1.23$ & $47.58^{\mathrm{b}} \pm 1.74$ & $54.64^{\mathrm{a}} \pm 3.87$ & $54.13^{\mathrm{a}} \pm 0.29$ \\
\hline Protein $(\%)$ & $27.33^{\mathrm{a}} \pm 0.58$ & $26.16^{\mathrm{b}} \pm 0.22$ & $24.2^{\mathrm{d}} \pm 0.44$ & $25.07^{\mathrm{c}} \pm 0.15$ & $26.56^{\mathrm{b}} \pm 0.15$ & $26.22^{\mathrm{b}} \pm 0.15$ \\
\hline Ash (\%) & $4.80^{\mathrm{b}} \pm 0.10$ & $4.78^{b} \pm 0.06$ & $5.07^{\mathrm{a}} \pm 0.05$ & $4.11^{\mathrm{b}} \pm 0.06$ & $5.72^{\mathrm{a}} \pm 0.17$ & $5.15^{\mathrm{a}} \pm 0.17$ \\
\hline
\end{tabular}

${ }^{*}$ Calculated by difference; the values followed by the same letter (in each row) are not significantly variance $(p \leq 0.05)$.

For heritability estimates, data in (Tab. 5) indicated that four traits out of eight recorded the highest heritability values over $90 \%$. These traits were oil yield/ha (99.56\%), seed yield ton/ha $(98.83 \%)$, plant height $(96.33 \%)$ and seed index $(90.03 \%)$. Meanwhile, the rest of the studied characters showed relatively medium intermediate heritability percentage such as the number of branches/plant $(58.72 \%)$.

The number of capsules plant had the highest estimated of genetic advance coupled with high broad-sense heritability thus, these characters seem to be highly heritable, points to the predominance of additive gene effect, easily fixable and can be taken as unit characters for effective selection. Length of fruiting zone and seed yield/plant expressed moderate heritability and low genetic advance, indicating the role of non-fixable genetic variance in the expression of these traits. These results were in harmony with that obtained by Kumar and Sasivannan (2006), Iwo et al. (2007), Ahmed et al. (2013), and Abd-Elsaber and Teileb (2019).

\subsection{Approximate chemical composition of sesame genotypes}

The proximate chemical composition of different sesame genotypes was shown in Table 6 . The results obtained in Table 6 showed that there are slight differences between all the different sesame genotypes in moisture content, where the results revealed that the $\mathrm{G} 2$ is the lowest in moisture content (4.51\%), while the control sample showed the highest moisture content (5.83\%). Alege and Mustapha (2013) reported, in the study of 23 genotypes of Nigerian sesame, that moisture contents ranged from 0.25 to $3.00 \%$. Whereas, they are less than the ratios obtained in our samples, this difference may be due to the genetic variation, weather, location and the environment. The crude oil content of sesame genotypes ranged from 39.56 to $54.64 \%$ of dry weight. Significant differences in sesame oil content were observed among the genotypes. G5 showed the highest content of oil followed by G6, G4 and G2, while G3 was the lowest in oil contents. The composition of the sesame seed is dependent on genetic, environmental factors, genotype, cultivation, climate, ripening stage, the harvesting time of the seeds and the analytical method used (Yasothai 2014; Rababah et al., 2017; A hmed et al., 2018). G5 was characterized by its higher protein content (26.56\%) after $\mathrm{G} 1$ (control) and G6 recorded $26.22 \%$ followed by G2 $(26.16 \%)$ then G4 (25.07\%), and finally G3 (24.20\%), respectively. The tested genotypes G2, G3, G4, G5 and G6 showed no significant $(p \leq 0.05)$ difference content in ash $(4.78,5.07,4.11,5.72$ and $5.15 \%$, respectively) as compared with control $(4.80 \%)$. The fibre content of the G6 sample increased significantly to the highest level (4.67\%) and decreased to the lowest level (3.31\%) in control genotype. Finally, Carbohydrate content calculated by difference and the results clarified that G5 genotype recorded the lowest level (13.08\%) while the sample of G3 genotype recorded the highest level $(31.17 \%)$. These results are approached with that obtained by Onsaard (2012), Prakash and Naik (2014), Yasothai (2014), and Rababah et al. (2017). 
H.A. Zahran et al:: OCL 2020, 27, 39

Table 7. Physicochemical properties of oil extracted from different sesame genotypes.

\begin{tabular}{lrrrrrr}
\hline Properties & \multicolumn{5}{c}{ Sesame oil } \\
\cline { 2 - 7 } & G1 (control) & \multicolumn{1}{c}{ G2 } & G3 & G4 & G5 \\
\hline Refractive index & $1.4661^{\mathrm{b}} \pm 0.001$ & $1.4711^{\mathrm{a}} \pm 0.001$ & $1.4711^{\mathrm{a}} \pm 0.001$ & $1.4692^{\mathrm{b}} \pm 0.001$ & $1.4707^{\mathrm{a}} \pm 0.001$ & $1.4677^{\mathrm{b}} \pm 0.001$ \\
Acidity \% (as oleic acid) & $0.33^{\mathrm{c}} \pm 0.02$ & $0.35^{\mathrm{b}} \pm 0.02$ & $0.32^{\mathrm{d}} \pm 0.01$ & $0.37^{\mathrm{a}} \pm 0.02$ & $0.28^{\mathrm{e}} \pm 0.01$ & $0.31^{\mathrm{d}} \pm 0.01$ \\
Peroxide value (mEq./kg) & $1.34^{\mathrm{b}} \pm 0.12$ & $1.12^{\mathrm{b}} \pm 0.09$ & $1.17^{\mathrm{b}} \pm 0.16$ & $2.87^{\mathrm{a}} \pm 0.32$ & $1.01^{\mathrm{b}} \pm 0.03$ & $1.67^{\mathrm{b}} \pm 0.11$ \\
Iodine value (g/100g) & $106.53^{\mathrm{b}} \pm 0.32$ & $105.95^{\mathrm{bc}} \pm 0.18$ & $105.38^{\mathrm{bc}} \pm 0.13$ & $108.39^{\mathrm{a}} \pm 0.08$ & $106.92^{\mathrm{b}} \pm 0.67$ & $104.95^{\mathrm{c}} \pm 0.38$ \\
Unsaponifiable matter (g/100g) & $1.22^{\mathrm{c}} \pm 0.13$ & $1.18^{\mathrm{b}} \pm 0.14$ & $1.11^{\mathrm{b}} \pm 0.12$ & $0.92^{\mathrm{a}} \pm 0.17$ & $1.65^{\mathrm{d}} \pm 0.15$ & $0.99^{\mathrm{a}} \pm 0.35$ \\
Total phenolic content, TPC $(\mathrm{mg} / \mathrm{g})$ & $13.66^{\mathrm{b}} \pm 0.88$ & $2.80^{\mathrm{d}} \pm 0.44$ & $13.98^{\mathrm{b}} \pm 0.44$ & $4.97^{\mathrm{d}} \pm 0.89$ & $18.32^{\mathrm{a}} \pm 0.40$ & $11.49^{\mathrm{c}} \pm 0.31$ \\
\hline
\end{tabular}

The values followed by the same letter (in each row) are not significantly variance $(p \leq 0.05)$.

\subsection{Physicochemical properties of oil extracted from different sesame genotypes}

\subsubsection{Oil characteristics}

The results obtained from the study are presented in Table 7. The Data shows the values of the oil properties measured from the extracted oil from different sesame genotypes. Refractive indices (RI) of sesame oil extracted from different genotypes were slightly significantly varied. The values of RI obtained from sesame oil samples are similar to those of a wide range of vegetable oils. The higher values of the characteristics reported for the crude oils revealed the necessity to purify the oils. As reported by Bello and Olawore (2012) and Aniołowska et al. (2016) the high RI values of oil due to the presence of long-chain fatty acids.

Acid value can catalyse oxidative decay of oils by enzymatic and chemical hydrolysis to form off volatile components. The free fatty acid percent refers to the possible hydrolytic retrogression of the oil (Zahran and Tawfeuk, 2019). The acidity \% (as oleic acid) of the sesame oil samples ranged from 0.28 to $0.37 \%$ (Tab. 7 ), the data revealed that there are low significance variations between sesame samples. Based on the foregoing, we have noticed that the difference in the content of free fatty acids of different samples may not be related to the genotype, but it may be accidental.

Peroxide value is an indicator of peroxidation, and therefore the high peroxide value of the oil is a hint to a weak oil resistance to peroxidation during storage and signals to a deterioration level (Adebayo et al., 2012; Mohamed et al., 2018). The peroxide number of different genotypes of sesame oil have significantly the highest value of $2.87 \mathrm{mEq}$./ $\mathrm{kg}$ for $\mathrm{G} 4$, while found the lowest value of $1.01 \mathrm{mEq} / \mathrm{kg}$ for G5 (Tab. 7). The peroxide value of all genotypes was in acceptable values (maximum acceptable value of $10 \mathrm{mEq} . / \mathrm{Kg}$ set by the Codex Alimentarius Commission (1999).

The data in Table 7 showed that the iodine value of sesame genotypes ranged from 104.95 to $108.39 \mathrm{~g} / 100 \mathrm{~g}$ oil in all genotypes. The highest iodine value was found in G4 and the lowest in G6. The iodine number was used to define the degree of unsaturation and stability of sesame oil samples (Naeem et al., 2019). Earlier, it was suggested that the iodine value should not be too high because it will increase the rate of oxidation and it should also not be too low, because it will affect its physical property (Sher and Hussain, 2009).

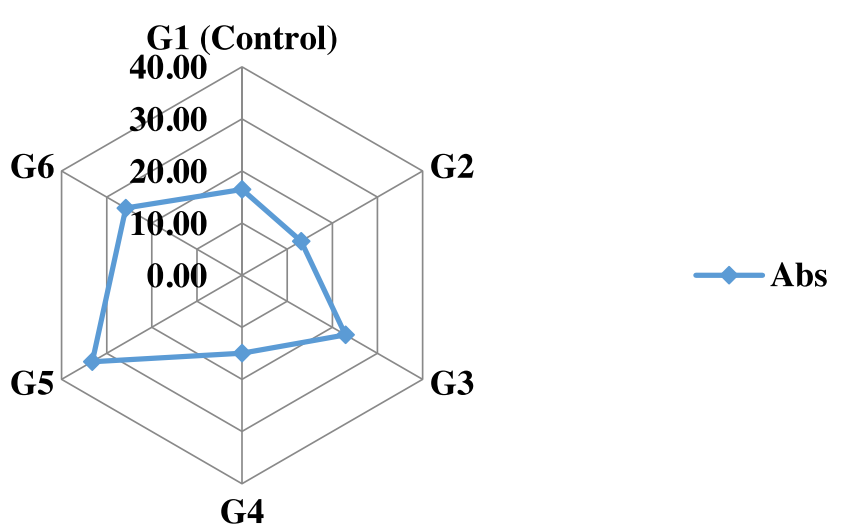

Fig. 1. Photometric colour index of different sesame oil samples.

The presence of unsaponifiable matter directly affected the oxidative stability of vegetable oils (Abou-Gharbia et al., 2000). Unsaponifiable matter content of sesame oil samples ranged from 0.92 to $1.65 \mathrm{~g} / 100 \mathrm{~g}$, the highest value of unsaponifiable matter was found in $\mathrm{G} 5(1.65 \mathrm{~g} / 100 \mathrm{~g})$ followed by G1 (control), G2 and G3, however, G6 and G4 were in lowest levels of unsaponifiable matter content. The unsaponifiable matter content varied significantly $(p \leq 0.05)$ in all genotypes.

Photometric color index (PCI) of sesame oil samples was shown in Figure 1. The spectrophotometric measurement has been proposed to establish a method to control the decolorization of oils. The absorption spectrum changes considerably as a function of the relative percentages of pigments occurring in them (Borello and Domenici, 2019). A large part of fluorescence in vegetable oils is caused by the presence of chlorophyll groups, $\beta$-carotene and tocopherols. (Nikolova et al., 2012). From the results in Figure 1, G5 has the highest absorption, as well as the highest oxidative stability $(\mathrm{IP}=26.57 \pm 0.27 \mathrm{~h})$ in comparison with the other samples, this is maybe due to the presence of $\beta$-carotene and tocopherols.

\subsubsection{Total phenolic content (TPC)}

The obtained data revealed that the level of total phenolic content (TPC) of sesame oil samples was shown in Table 7. The TPC of different samples was varied significantly $(p \leq 0.05)$ and ranging from $2.80 \pm 0.44$ to $18.32 \pm 0.40 \mathrm{mg}$ GAE $\mathrm{g}^{-1}$. G5 showed the highest in TPC $(18.32 \pm 0.40 \mathrm{mg}$ 


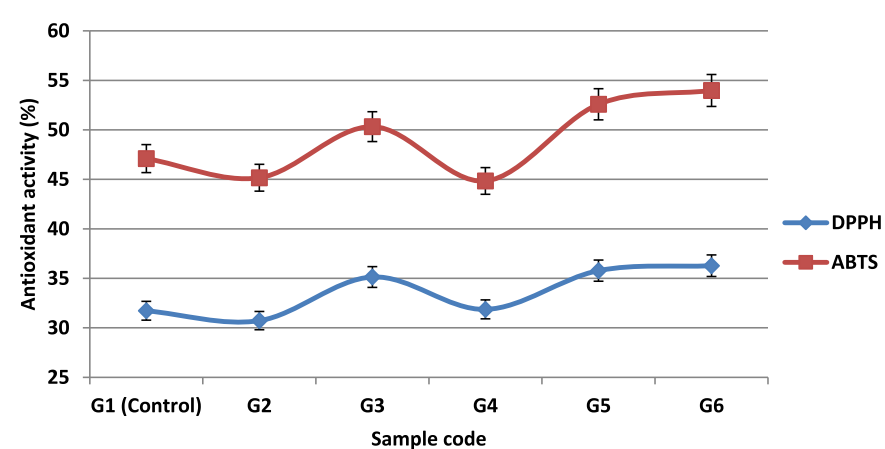

Fig. 2. Means antioxidant activities and standard errors $(n=3)$ of sesame oil samples by DPPH and ABTS radical scavenging activity.

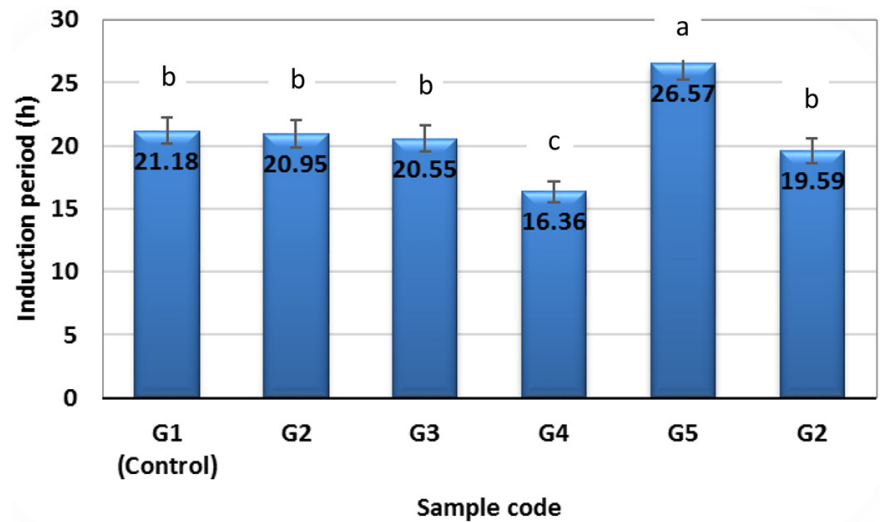

Fig. 3. Means induction time $(h)$ and standard errors $(n=3)$ of sesame oil samples by Rancimat test.

Table 8. Fatty acid profile of sesame oil genotypes.

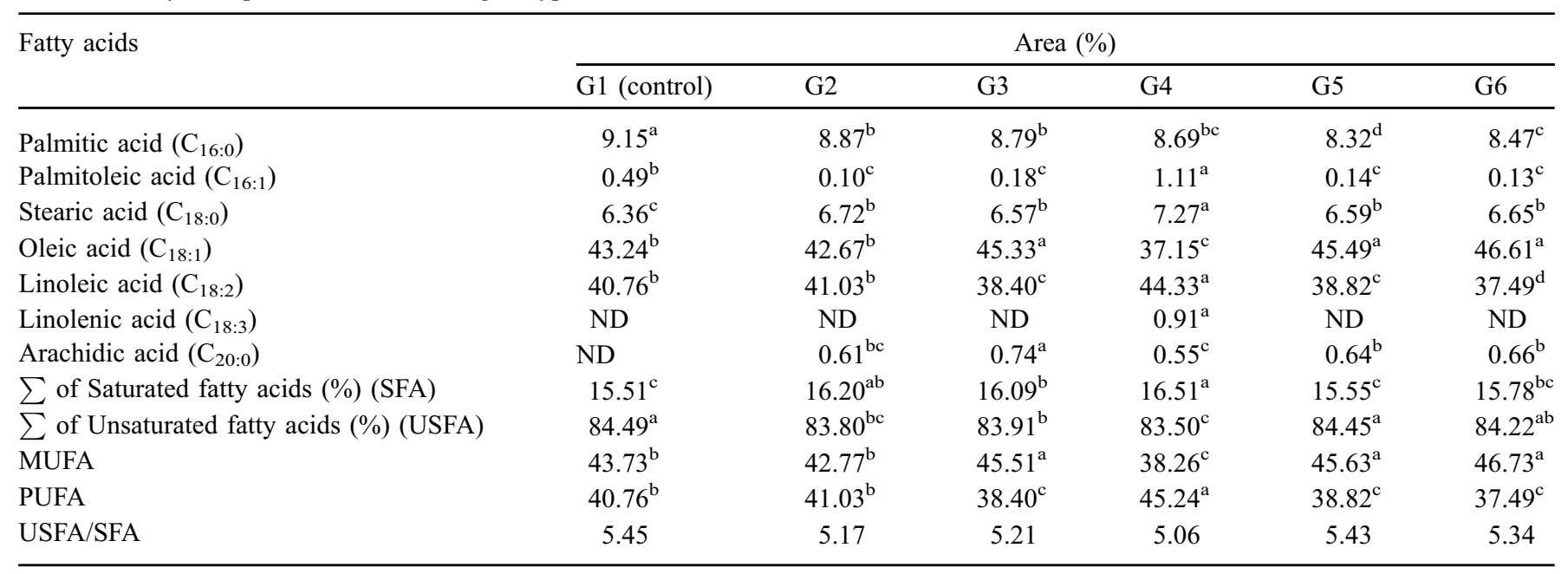

${ }^{* *} \mathrm{Nd}=$ Not detectable; the values followed by the same letter (in each row) are not significantly variance $(p \leq 0.05)$.

$\mathrm{GAE}^{-1}$ ), while the lowest was observed in oil $\mathrm{G} 2$ $\left(2.80 \pm 0.44 \mathrm{mg} \mathrm{GAE}^{-1}\right)$, which has a significant difference $(p \leq 0.05)$ is compared with other samples (Tab. 7). This study showed that sesame oil samples of different genotypes varied phenolic contents. Many scientists concluded that there is a positive correlation between the antioxidant activity and content of phenolics (Wang et al., 2017).

\subsubsection{Antioxidant activity by DPPH and ABTS method}

The effect of sesame genotype on antioxidant activity of sesame oil whether using DPPH or ABTS free radical scavenging activity (Fig. 2). The results showed that G6 exhibited the highest DPPH and ABTS scavenging activity ( 36.27 and $53.98 \%$, respectively) followed by G5 with DPPH and ABTS radical scavenging activity by 35.78 and $52.58 \%$, respectively. From the graph in Figure 2, we notice that the variation of genotypes affected significantly the antioxidant activity of sesame extracted oil. Elhussein et al. (2018) concluded that lipid oxidation of sesame oil is greatly affected by the presence of phytonutrients, as well as its origin. When these appropriate correlations hold, we could conclude that phenolic compounds in sesame oil are predominantly responsible for its antioxidant activity.

\subsection{Fatty acid composition}

The variances among the sesame genotypes were statistically significant (at level $p \leq 0.05$ ) for saturated fatty acids such as palmitic $\left(\mathrm{C}_{16: 0}\right)$, stearic $\left(\mathrm{C}_{18: 0}\right)$ and arachidic $\left(\mathrm{C}_{20: 0}\right)$ acids in all genotypes. The ranges of fatty acids differ from 8.32 to $9.15 \%$ of palmitic acid $\left(\mathrm{C}_{16: 0}\right), 6.36$ to $7.27 \%$ of stearic acid $\left(\mathrm{C}_{18: 0}\right)$ and 0.55 to $0.74 \%$ of arachidic acid $\left(\mathrm{C}_{20: 0}\right)$ but we found that arachidic acid was not detected in control genotype (Tab. 8). Statistically little significant variances between sesame genotypes were showed for saturated fatty acids in all sesame genotypes under study. The chief saturated fatty acids are palmitic acid (7-12\%) and stearic acid (3.5-6\%). The data obtained by Mehta (2000) was in the same manner of our obtained data.

For unsaturated fatty acids, statistically significant variances $(p \leq 0.05)$ were found between sesame genotypes for the major unsaturated fatty acids such as oleic $\left(\mathrm{C}_{18: 1}\right)$ and 
linoleic acid $\left(\mathrm{C}_{18: 2}\right)$ percentage in all genotypes. According to different species, the palmitoleic acid $\left(\mathrm{C}_{16: 1}\right)$ percentage ranged from 0.10 to $0.49 \%$, the oleic acid $\left(\mathrm{C}_{18: 1}\right)$ percentage ranged from 37.15 to $46.61 \%$, linoleic acid $\left(\mathrm{C}_{18: 2}\right)$ content ranged from 37.49 to $44.33 \%$, and linolenic acid $\left(\mathrm{C}_{18: 3}\right)$ were not detected in all genotypes except in G4 was $0.91 \%$ (Tab. 8). In this investigation, a variation among the sesame species was in observed for oleic acid $\left(\mathrm{C}_{18: 1}\right)$ and linoleic acid $\left(\mathrm{C}_{18: 2}\right)$ percent. The predominant unsaturated fatty acids are oleic (35$50 \%$ ) and linoleic acid (35.5-41.2\%) (Mehta, 2000). Unsaturated fatty acids have a favourable effect and positive health benefit than saturated fatty acids (Soliman et al., 2019), The fatty acid composition of sesame oil was within the range of the results reported by Elleuch et al. (2007) and Uzun et al. (2002). Total of saturated fatty acids (SFA) ranged from 15.51 to $16.51 \%$, on the other hand, a total of unsaturated fatty acids (USFA) ranged from 83.50 to $84.49 \%$.

\subsection{Oxidative stability of sesame oil samples}

The oxidative stability of the vegetable oil is a marker of quality and integrity for their potential applications and utilization in foods, and it depends especially on the fatty acid composition, as well as the content of antioxidant of these oils (Abdelazim et al., 2013; Zahran and Soliman, 2018). According to the results of oxidative stability, it was found that the sesame samples have a wide range of induction period (IP), which ranged from $16.36 \pm 0.32$ to $26.57 \pm 0.27 \mathrm{~h}$ (Fig. 3), as measured by Rancimat at $110^{\circ} \mathrm{C}$. Sesame oil extracted from G5 (Imported 554) had the highest IP $(26.57 \pm 0.27 \mathrm{~h})$, followed by G1, G2, G3 and G6 with IP $21.18 \pm 0.24$, $20.95 \pm 0.61,20.55 \pm 0.12$ and $19.59 \pm 0.19 \mathrm{~h}$, respectively. However, the G4 had the lowest IP $(16.36 \pm 0.32 \mathrm{~h})$. The variation of stability in sesame oil samples may be due to the presence of unique unsaponifiable constituents namely lignans and tocopherols (Abou-Gharbia et al., 2000).

\section{Conclusion}

This investigation was carried out to characterize six sesame genotypes during two successive seasons, 2017 and 2018. The results indicated that G4 was the highest in most traits under study. High estimates of (PCV) and (GCV) were exhibited for the number of branches/plant and number of capsules/plant. The high heritability was exhibited for seed yield/ha, plant height, oil yield/ha, and seed index. The number of capsules/plants that had the highest estimated of genetic advance coupled with high broad-sense heritability thus, these characters seem to be highly heritable, points to the predominance of the additive gene effect, easily fixable and can be taken as a unit character for effective selection. From this study, it could be concluded that the oil extracted from different sesame genotypes meet the international quality standards in terms of oil content and fatty acid composition. The sesame oil in particular G5 had the highest oxidative stability due to the presence of the high amount of unsaponifiable matter. The existence of high amounts of unsaturated fatty acids (oleic \& linoleic acids) as compared to saturated fatty acids, support the convenience of the investigated sesame genotypes for nutritional applications.

\section{References}

Abd-El-Rhman Rehab HA, Shafi Wafaa WM. 2016. Lin X tester analysis in sesame. Egypt J Plant Breed 20(5): 695-704.

Abd-Elsaber A, Teileb WMK. 2019. Evaluation of some sesame genotypes for yield and its components under Upper Egypt conditions. Egypt J Plant Breed 23(5): 785-799.

Abd-Elsaber A, Ahmed HK, Teileb WMK. 2018. Performance and stability of some new sesame genotypes under various environments in Egypt. In: Proceeding of The Seventh Field Crop Conference, 18-19 Dec. 2018, Giza, Egypt, pp. 93-105.

Abdelazim AA, Mahmoud A, Ramadan-Hassanien MF. 2013. Oxidative stability of vegetable oils as affected by sesame extracts during accelerated oxidative storage. J Food Sci Tech 50 (5): 868-878.

Abou-Gharbia HA, Shehata AA, Shahidi F. 2000. Effect of processing on oxidative stability and lipid classes of sesame oil. Food Res Int 33(5): 331-340.

Adebayo SE, Orhevba BA, Adeoye PA, Musa JJ, Fase OJ. 2012. Solvent extraction and characterization of oil from African star apple (Chrysophyllumalbidum) seeds. Acad Res Inter 3(2): 178.

Aglave HR. 2018. Physiochemical characteristics of sesame seeds. $J$ Med Plants Stud 6(1): 64-66.

Ahmed Fadia HA, Hassanein AM, EL-demardash IS. 2013. Evaluation and genetic diversity of eleven sesame lines. Egypt $J$ Genet Cytol 42: 205-222.

Ahmed DM, Zahran HA, Zaher FA, Abd Ei-Hamid MA, Ei-Hamidi MA. 2018. Jatropha tree productivity, seed oil content and oil quality as feed stock for biodiesel production. Biosci Res 15(3): 2134-2140.

Alege GO, Mustapha OT. 2013. Assessment of genetic diversity in Nigerian sesame using proximate analysis. Global J Bio Biotech 2 (1): 57-62.

Alimentarius C. 1999. Codex standard for named vegetable oils. Codex Stan 210: 1-3.

Aniołowska M, Zahran H, Kita A. 2016. The effect of pan frying on thermooxidative stability of refined rapeseed oil and professional blend. J Food Sci Tech 53(1): 712-720.

AOAC. 2000. Official methods of analysis. Washington: Association of Official Analytical Chemists.

AOCS. 1997. Official and tentative methods of the American Oil Chemists' Society. Champaign, USA: AOCS Press.

Bhattachary CH, Pandey BH, Paroha SE. 2014. Effect of storage on mineral components and anti-nutritional characters of sesame (Sesamumindicum L.) seeds. Indian J Med Res 4: 25-30.

Bello MO, Olawore NO. 2012. Potentials of two uncultivated plants in nutrition and industrial development. Adv Food Energy Sec 2: 10-16.

Borello E, Domenici V. 2019. Determination of pigments in virgin and extra-virgin olive oils: A comparison between two near UVVis spectroscopic techniques. Foods 8(1): 18.

Carlsson AS, Chanana NP, Gudu S, Suh MC. 2009. Were BA. Sesame. Compendium Transgenic Crop Plants 15: 227-246.

Carrasco-Pancorbo A, Cerretani L, Bendini A, et al. 2005. FernandezGutierrez A. Evaluation of the antioxidant capacity of individual phenolic compounds in virgin olive oil. J Agric Food Chem 53 (23): 8918-8925.

Dossa K, Wei X, Zhang Y, et al. 2016. Analysis of genetic diversity and population structure of sesame accessions from Africa and Asia as major centers of its cultivation. Genes 7(4): 14.

El-Shakhess SA, Abdel-Tawab YM, Nemat AN. 2008. Evaluation and differentiation of eleven sesame lines. Egypt J Plant Breed 12: $1-25$. 
Elhussein E, Bilgin M, Sahin S. 2018. Oxidative stability of sesame oil extracted from the seeds with different origins: Kinetic and thermodynamic studies under accelerated conditions. $J$ food Pro 41(8): e12878.

Elleuch M, Besbes S, Roiseux O, Blecker C, Attia H. 2007. Quality characteristics of sesame seeds and by-products. Food Chem 103 (2): 641-650.

Gnanasekaran M, Jebaraj S, Muthuramu S. 2008. Correlation and path co-efficient analysis in sesame (Sesamum indicum L.). Plant Arch 8(1): 167-169.

Hassan MS, Sedeck FS. 2015. Combining ability and heterosis estimates in sesame. World App Sci J 33(5): 690-698.

Hika G, Geleta N, Jaleta Z. 2015. Genetic variability, heritability and genetic advance for the phenotypic traits in sesame (Sesamum indicum L.) populations from Ethiopia. Sci Tech Arts Res J 4(1): 20-26.

Iwo GA, Idowu AA, Misari S. 2007. Genetic variability and correlation studies in sesame (Sesamum indicum). Global J Pure App Sci 13(1): 35-38.

Kanu PJ, Bahsoon JZ, Kanu JB, Kandeh JB. 2010. Nutraceutical importance of sesame seed and oil: a review of the contribution of their lignans. Sierra Leone J Biomed Res 2(1): 4-16.

Kumar PS, Sasivannan S. 2006. Variability, heritability and genetic advance in sesamum (Sesamumindicum L.). Crop Res Hisar 31 (2): 258 .

Langham DR. 2008. Growth and development of sesame. Sesaco Corp 329.

Mehta BV. 2000. Sea Millennium Handbook 2000, 7th ed. Mumbai: The Solvent Extractors Association of India.

Minioti KS, Georgiou CA. 2010. Comparison of different tests used in mapping the Greek virgin olive oil production for the determination of its total antioxidant capacity. Grasas y aceites 61(1): 45-51.

Mohamed FA, Salama HH, El-Sayed SM, El-Sayed HS, Zahran HA. 2018. Utilization of natural antimicrobial and antioxidant of Moringa oleifera leaves extract in manufacture of cream cheese. $J$ Bio Sci 18(2): 92-106.

Naeem MA, Zahran HA, Hassanein MM. 2019. Evaluation of green extraction methods on the chemical and nutritional aspects of roselle seed (Hibiscus sabdariffa L.) oil. OCL 26: 33.

Nikolova K, Eftimov T, Perifanova M, Brabant D. 2012. Quick fluorescence method for the distinguishing of vegetable oils. $J$ Food Sci Eng 2: 674-684.

Onsaard E. 2012. Sesame proteins. Int Food Res J 19(4): 1287-1295.

Otieno BA, Krause CE, Rusling JF. 2016. Bioconjugation of antibodies and enzyme labels onto magnetic beads. Methods Enzymol (Academic Press) 571: 135-150.

Prakash K, Naik SN. 2014. Bioactive constituents as a potential agent in sesame for functional and nutritional application. J Bio Eng Tech 1: 48-66.

Rababah T, Al-U'datt MU, Al-Mahasneh MA, Odeh A, Ajouly T, Feng H. 2017. Effect of processing and storage at different temperatures on the physicochemical and minerals content of sesame seeds and tehina. Bulgarian J Agric Sci 23(5): 851-859.

Sankar PD, Kumar CR. 2003. Character association and path coefficient analysis in sesame (Sesamum indicum L.). Agric Sci Digest 23(1): 17-19.

Senila L, Neag E, Cadar O, Kovacs MH, Becze A, Senila M. 2020. Chemical, nutritional and antioxidant characteristics of different food seeds. App Sci 10(5): 1589.

Sher H, Hussain F. 2009. Ethnobotanical evaluation of some plant resources in Northern part of Pakistan. Afr J Bio 8(17).

Soliman TN, Farrag AF, Zahran HA, El-Salam ME. 2019. Preparation and Properties Nano-encapsulated Wheat germ oil and its use in the manufacture of functional labneh cheese. PakJ Bio Sci 22(7): 318-26.

Steel RGD, Torrie JH, Dickey DA. 1997. Principles and procedures of statistics: A biometrical approach, 3rd ed. New York, USA: McGraw Hill.

Tamina B, Dasgupta T. 2003. Character association in sesame (Sesamum indicum L.). Indian Agric 47: 253-258.

Uzun B, Ulger S, Cagirgan MI. 2002. Comparison of determinate and indeterminate types of sesame for oil content and fatty acid composition. Turkish J Agric Forest 26(5): 269-274.

Wacal C, Ogata N, Basalirwa D, et al. 2019. Fatty acid composition of sesame (Sesamum indicum L.) seeds in relation to yield and soil chemical properties on continuously monocropped upland fields converted from paddy fields. Agronomy 9(12): 801.

Wang S, Chu Z, Ren M, et al. 2017. Identification of anthocyanin composition and functional analysis of an anthocyanin activator in solanumnigrum fruits. Molecules 22(6): 876.

Wei X, Gong H, Yu J, et al. 2017. Sesame FG: an integrated database for the functional genomics of sesame. Sci Rep 7(1): 10.

Were BA, Onkware AO, Gudu S, Welander M, Carlsson AS. 2006. Seed oil content and fatty acid composition in East African sesame (Sesamum indicum L.) accessions evaluated over 3 years. Field Crops Res 97(2-3): 254-260.

Wheeler TR, Craufurd PQ, Ellis RH, Porter JR, Prasad PV. 2000. Temperature variability and the yield of annual crops. Agric Eco Envi 82(1-3): 159-167.

Yasothai R. 2014. Chemical composition of sesame oil cake-Review. Int J Sci Envir Tech 3: 827-835.

Zaher F, Gad MS, Aly SM, Hamed SF, Abo-Elwafa GA, Zahran HA. 2017. Catalytic cracking of vegetable oils for producing biofuel. Egypt J Chem 60(2): 291-300.

Zahran H, Najafi Z. 2019. Enhanced stability of refined soybean oil enriched with phenolic compounds of olive leaves. Egypt J Chem 63(1): 215-224.

Zahran HA, Soliman HM. 2018. UPLC-Q-TOF/MS screening of bioactive compounds extracted from olive mill solid wastes and their effect on oxidative stability of purslane seed oil. Curr Sci Int 7(2): 307-319.

Zahran HA, Tawfeuk HZ. 2019. Physicochemical properties of new peanut (Arachis hypogaea L.) varieties. OCL 26: 19.

Cite this article as: Zahran HA, Abd-Elsaber A, Tawfeuk HZ. 2020. Genetic diversity, chemical composition and oil characteristics of six sesame genotypes. OCL 27: 39. 